Research Article

\title{
Geno-Toxic Appraisal of Widely Used Food Color Additives on Model Plant Allium cepa Root Tip Cells
}

\author{
Jabeen Farheen ${ }^{1,2 *}$, Simeen Mansoor ${ }^{1}$ and Maria Abid ${ }^{1}$ \\ ${ }^{1}$ Department of Genetics, KU Circular Road, Faculty of Science, University of Karachi, Main University Road, Karachi-75270, \\ Sindh, Pakistan. ${ }^{2}$ School of Material Science and Engineering, Zhejiang Sci-Tech University, Hangzhou, 310018, China.
}

\begin{abstract}
The frequent use of meal and beverages having food color additives (FCAs) may cause mutation in humans' proto-oncogenes which leads to carcinogenicity. The current findings aimed to evaluate the genotoxic impact of widely used azo FCAs on the cell cycle by using onion as a model plant. The study was designed in a complete randomized design where the grown onion roots were exposed to $0 \%, 0.001 \%, 0.01 \%, 0.1 \%$, and $1 \%$ concentration of FCA for 120 hours for macroscopic and $36 \mathrm{~h}$ for microscopic evaluation. The onion root tips morpho-physiology was severely affected as the concentration of FCAs increased. The macroscopic analysis manifested that allura red had $95 \%$ broken-ended extremely thin and transparent root tips at $1 \%$ concentration. In the microscopic analysis, FCAs induced eight different kinds of chromosomal aberrations in which allura red significantly induced the highest frequencies of abnormal prophase, sticky metaphase, c-mitosis, sticky anaphase, and laggard anaphase at each concentration. While, dislocated metaphase, forwarded anaphase, and bridge anaphase were only found in sunset yellow, tartrazine, and fast green, respectively. The use of evaluated FCAs especially allura red in foodstuff, cosmetics, and skincare products can cause cancer in humans.

Received | June 20, 2020; Accepted | March 18, 2021; Published | June 11, 2021

*Correspondence | Jabeen Farheen, Department of Genetics, KU Circular Road, Faculty of Science, University of Karachi, Main University Road, Karachi-75270, Sindh, Pakistan; Email: jabeenfarheen@hotmail.com; jabeenfarheen87@zstu.edu.cn

Citation | Farheen, J., S. Mansoor and M. Abid. 2021. Geno-toxic appraisal of widely used food color additives on model plant Allium cepa root tip cells. Journal of Innovative Sciences, 7(1): 174-181.

DOI | https://dx.doi.org/10.17582/journal.jis/2021/7.1.174.181

Keywords | Chromosomal aberrations, Cytotoxicity, Food dye, Mitotic index, Onion
\end{abstract}

\section{Introduction}

$\mathrm{T}$ he azo dyes are a large group of low-cost, synthetic food colour additives (FCA) with no taste and nutritional value. It is widely utilized to attract and enhance the acceptability of consumers for bakery products, candies, sweets, chewing gum, sauces, jams, jelly, noodles, frozen desserts, beverages, wine, processed seafood, daily used skincare products, hand sanitizers, soaps, cosmetics and pharmaceuticals (Dwivedi and Kumar, 2015; Floriano et al., 2018; Vidal et al., 2018; Kaur et al., 2019; Khan et al., 2020). Azo dyes are consisted of nitrogen and carbon atom having $\mathrm{R}-\mathrm{N}=\mathrm{N}-\mathrm{R}$ ' functional group in which $\mathrm{Rs}$ is usually aryl. The delocalization of aryl gives vivid colors such as red, orange, and yellow. It is usually produced by an electrophilic substitution reaction of an aryl diazotization with acetoacetic amide or aromatic amines (Clarke and Kirner, 1941), which are well documented carcinogenic and mutagenic agents (Khan et al., 2020).

Several studies have been conducted on the nature and characterization of azo dyes which presented a higher level of cytotoxicity on plants cells, severe allergic reactions in humans, and even cancer in lab-tested animals than any other synthetic FCAs (Rangan and Barcelous, 2009; Micic et al., 2014; Kaur et al., 
2019). The carmoisine or azorubine, metanil yellow, sunset yellow, tartrazine, and brilliant blue CFC induced number of mitotic aberrations in onion's meristematic cells such as micronuclei, binucleate cell, fragmentation, c-mitosis, bridge anaphase, laggard, forwarded, and stickiness at meta and anaphase of chromosomes (Kaur et al., 2019; Khan et al., 2020). Likewise, the allura red, sunset yellow, tartrazine, and fast green azo dye causes abdominal pain, headache, nausea, eczema, eye, and skin rashes and swelling as well as asthma in children (Freitas, 2012; Oliveira et al., 2013). In guinea pigs, 3\% carmoisine (red azo dye) and tartrazine (yellow azo dye) caused severe liver lesions, capillary congestion in extralobular and intralobular vessels, apoptosis in the hepatocyte, abnormal conditions in kidney tubular or glomerular stasis and filtration, pericanalicular and perivascular oedema and severe histopathological conditions, when administrated in drinking water for three weeks (Rus et al., 2010). Despite this, azo FCAs are still one of the most extensively used FCAs in foodstuff, and their use is permitted in a number of countries especially in Asia (Khan et al., 2020). However, it is banned in the United State of America, Norway, Finland, Austria, France, and the United Kingdom.

Although FCAs have been stated as possible causes of homeostatic ailments, there is a need for a more definitive clarification of the toxicity of azo FCAs, particularly its genotoxicity, as well as safe concentrations and doses used. In this context, there is a need for research to evaluate the toxicity of azo dyes. Thus, this study aimed to practically evaluate the toxic impact of four widely utilized azo FCAs such as allura red, sunset yellow, tartrazine, and fast green using various concentrations on onion bulb root tip cells, and as well as to estimate the minimum concentration prerequisite to induce chromosomal or cellular damage. Additionally, it can reflect the impact of FCAs on dividing cells of any living organisms including humans due to a lack of insufficient information on how these FCAs affect food safety.

\section{Materials and Methods}

\subsection{Test material and chemical substance}

The onion bulbs $(2 \mathrm{n}=16)$ of $2.0-2.5 \mathrm{~cm}$ in diameter and colour additives such as allura red AC (E129, $\left.\mathrm{C}_{18} \mathrm{H}_{14} \mathrm{~N}_{2} \mathrm{Na}_{2} \mathrm{O}_{8} \mathrm{~S}_{2}\right)$, sunset yellow FCF (E110, $\mathrm{C}_{16} \mathrm{H}_{10} \mathrm{~N}_{2} \mathrm{Na}_{2} \mathrm{O}_{7} \mathrm{~S}_{2}$ ), tartrazine (E102, $\mathrm{C}_{16} \mathrm{H}_{9} \mathrm{~N}_{2} \mathrm{Na}_{2} \mathrm{O}_{9} \mathrm{~S}_{2}$ ), and fast green FCF (E143,
$\mathrm{C}_{37} \mathrm{H}_{34} \mathrm{~N}_{2} \mathrm{Na}_{2} \mathrm{O}_{10} \mathrm{~S}_{3}$ ) were purchased from a local market in Karachi, Sindh, Pakistan.

\subsection{Macroscopic method}

Before initiate the macroscopic study, scrutiny have been done regarding FCA concentration. Then those concentrations were selected that were used commercially in local beverages, chattni, ketchup, etc. The series of color additives concentrations such as $0 \%$, $0.001 \%, 0.01 \%, 0.1 \%$, and $1 \%$ were prepared for each food color in deionized water. Thereat, the dry outer scales of onion bulbs were detached and adventitious roots from the bulb disc were prudently scraped without destroying the basal plate (Fiskesjo, 1985). The onion bulb disc was separately dipped in five concentrations of each colour additive's filled beakers and allowed to grow for $120 \mathrm{~h}$ at room temperature. On the $6^{\text {th }}$ day, four onion bulbs treatment ${ }^{-1}$ were taken for the study of root colour, root shape, root size, and vigor.

\subsection{Microscopic method}

For microscopic analysis, the onion bulbs were divided into two groups. The group -1 was $0 \%$ concentration or the control group that was treated with distilled water only. While food colour additives were group-2 that was first placed in the distilled water filled beaker until the adventitious root of onion bulbs became 1-2 $\mathrm{cm}$ long. Then onion bulbs were transferred into the separate beakers having different colour additives for $36 \mathrm{~h}$. After colour additives treatment, onion root tips were cut and preserved in "Farmer Fixative" for $24 \mathrm{~h}$ (Farheen and Mansoor, 2019). The onion root cells were hydrolyzed in the $1 \mathrm{~N}$ hydrochloric acid solution for 5 minutes at $60{ }^{\circ} \mathrm{C}$ then stained in $1.8 \%$ aceto-orcein for $24 \mathrm{~h}$ (Farheen and Mansoor, 2019). The mitotic index and chromosomal aberrations were captured by Nikon DS-F1 Japan at $100 \mathrm{x}$ objective lens and computed via formulae (Farheen and Mansoor, 2019).

\subsection{Statistical analysis}

The macroscopic and microscopic assays were conducted in a completely randomized design with four replicates during 2019, at the lab of the Department of Genetics, University of Karachi (Steel and Torrie, 1997). The four slides of each concentration per color additive were used to score at least 1000 cells for data authentication. Macroscopic and microscopic studies were analyzed through oneway analysis of variance of IBM SPSS version 19 
for each FCA. While the test of significance was accomplished through Duncan's Multiple Range Test at $p \leq 0.05 \%$ level of significance.

\section{Results and Discussion}

\subsection{Macroscopic analysis}

The macroscopic analysis of food colour additives showed a hazardous impact with its progressive concentration over the onion bulb root tip's morphology (Figure 1). The grown onion bulbs stunted in root tip growth and also displayed various destruction in root tip morphology like broken end and crochet hook as concentration enhanced from $0.001 \%$ to $1 \%$ FCA (Table 1 ). The $0 \%$ concentration of FCA exhibited $100 \%$ straight, thick and white root tips whereas, $0.001 \%$ solution of FCA showed a mixture of slightly thin, straight, and crochet hook white root tips. At $0.01 \%$ FCA level, all three kinds of studied root tips of onion were noted with thin and white colour. In contrary to the $0.001 \%, 0.01 \%$, and $0.1 \%$ levels, the $1 \%$ FCA indicated the highest frequencies of broken ended and lowest rate of crochet hook root tips with an extremely thin and transparent appearance. Among four FCA, allura red had maximumly broken-ended root tips at $1 \%$ conc. and crochet hook at $0.1 \%$ conc. followed by fast green FCA. While sunset yellow possessed utmost straight and lesser broken-ended and crochet hook root tips.

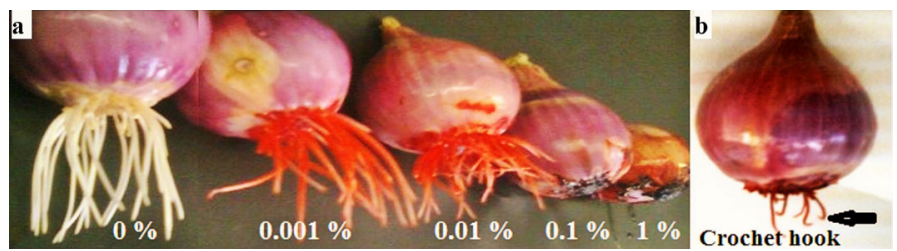

Figure 1: Macroscopic study of 120 hours old onion (Allium cepa) root tips treated with $0 \%, 0.001 \%$, $0.01 \%, 0.1 \%$ and $1 \%$ concentration of allura red food colour additive (a) and Crochet hooks root tips (b).

\subsection{Microscopic analysis}

Figure 2 revealed the mitotic index (MI) analysis of four FCA with its four concentrations. Among four FCA, the allura red has lowermost and sunset yellow FCA has a higher mitotic index after 0\% FCA at each concentration. The $0.001 \%$ concentration of sunset yellow prompted $55 \%$, tartrazine had $42 \%$, fast green had 38\%, and allura red FCA showed 35\%, cell division. Where, $1 \%$ concentration manifested $18 \%$ $\mathrm{MI}$ in sunset yellow, 13\% MI in tartrazine, 8\% $\mathrm{MI}$ in fast green, and 5\% MI in allura red FCA.
Table 1: Macroscopic analysis of onion (Allium cepa) and its root tips at various concentrations (Conc.) of food colour additives (FCA).

\begin{tabular}{lllll}
\hline Conc. (\%) & Treatment & \multicolumn{3}{l}{ Shape of onion root tips (\%) } \\
\cline { 3 - 5 } & & Straight & $\begin{array}{l}\text { Broken } \\
\text { end }\end{array}$ & $\begin{array}{l}\text { Crochet } \\
\text { hook }\end{array}$ \\
\hline $0 \%$ & Distilled water & 100 & 0 & 0 \\
$0.001 \%$ & Allura Red & 42 & 0 & 58 \\
& Sunset Yellow & 65 & 0 & 35 \\
& Tartrazine & 55 & 0 & 45 \\
& Fast Green & 50 & 0 & 50 \\
$0.01 \%$ & Allura Red & 21 & 18 & 61 \\
& Sunset Yellow & 46 & 15 & 39 \\
& Tartrazine & 37 & 16 & 47 \\
& Fast Green & 30 & 17 & 51 \\
$0.1 \%$ & Allura Red & 0 & 15 & 85 \\
& Sunset Yellow & 0 & 31 & 69 \\
& Tartrazine & 0 & 25 & 75 \\
& Fast Green & 0 & 22 & 78 \\
$1 \%$ & Allura Red & 0 & 95 & 05 \\
& Sunset Yellow & 0 & 82 & 18 \\
& Tartrazine & 0 & 87 & 13 \\
& Fast Green & 0 & 92 & 08 \\
\hline
\end{tabular}

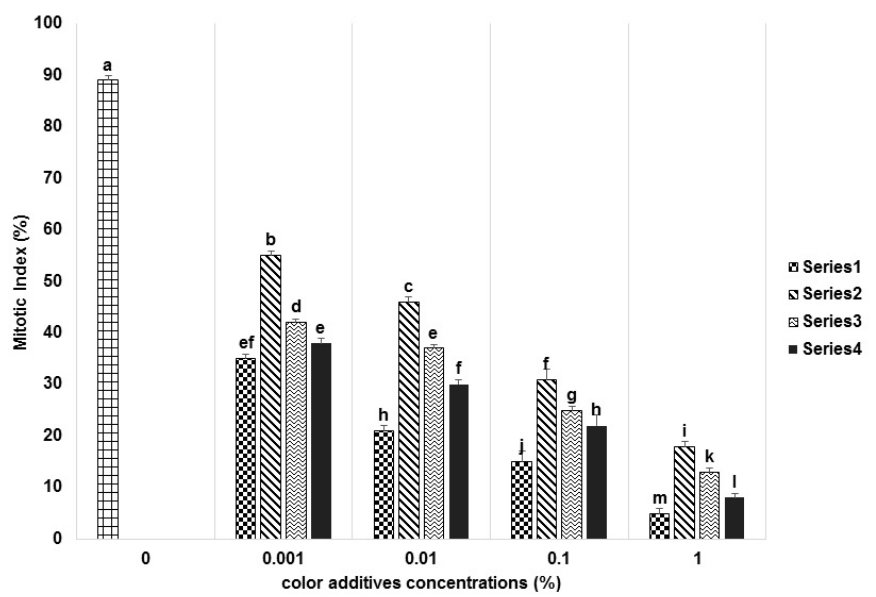

Figure 2: Mitotic index of onion (Allium cepa) root tips treated with $0 \%, 0.001 \%, 0.01 \%, 0.1 \%$ and $1 \%$ concentration of four used food colour additives. The first bar at $0 \%$ concentration showed control of the study while series-1 indicated the allura red, series- 2 indicated the sunset yellow, series- 3 indicated the tartrazine, and series -4 indicated fast green FCA bars. Similar letters are representing no difference among treatments of each FCA $(n=4)$.

In the case of mitotic aberrations, FCA caused eight different kinds of chromatin and spindle fiber-related chromosomal aberrations such as abnormal prophase (AP), sticky metaphase (SM), dislocated metaphase 
(DM), c-mitosis (C-M), forwarded anaphase (FA), sticky anaphase (SA), bridge anaphase (BA), and laggard anaphase (LA) in onion root tip cells. It was demonstrated that the maximum types of aberrations were found in allura red food additive in any concentration. It was observed that the $\mathrm{AP}$ occurrence was found highest (40\%) at $1 \%$ concentration allura red while minimum (6\%) in sunset yellow at $0.001 \%$ solution (Figure 3).

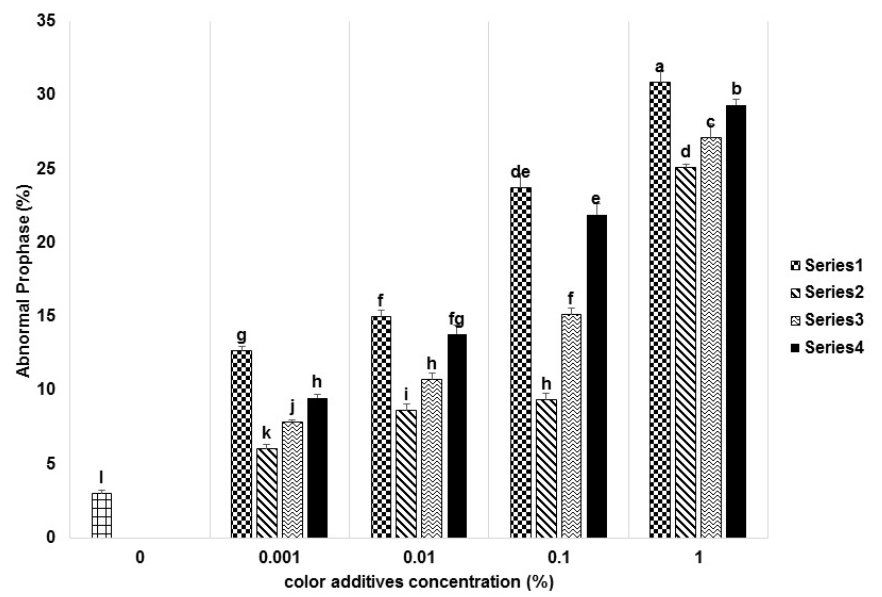

Figure 3: Abnormal prophase in onion (Allium cepa) root tips treated with $0 \%, 0.001 \%, 0.01 \%, 0.1 \%$ and $1 \%$ concentration of four used food colour additives. The rest of the information same as Figure 2.

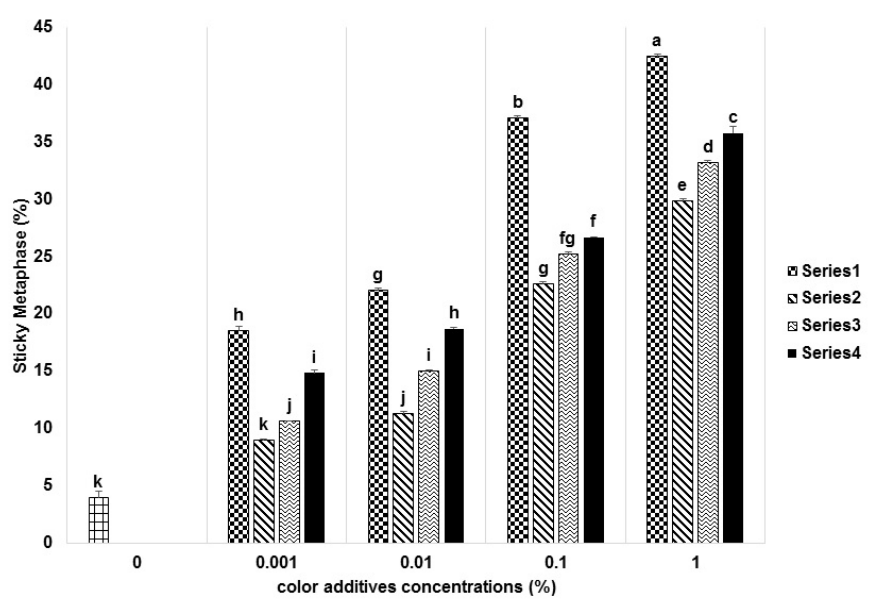

Figure 4: Sticky metaphase in onion (Allium cepa) root tips treated with $0 \%, 0.001 \%, 0.01 \%, 0.1 \%$ and $1 \%$ concentration of four used food colour additives. The rest of the information same as Figure 2.

Similarly, sticky metaphase, c-mitosis, and sticky anaphase anomaly were maximum in $1 \%$ allura red as compared to any FCA that were $43 \%, 16 \%$, and $11 \%$ respectively (Figures 4, 5 and 6). In contrast, SM, $\mathrm{C}-\mathrm{M}$, and SA aberrations were observed minimum at $0.001 \%$ concentration of sunset yellow FCA. The sticky anaphase aberration was not seen at $1 \%$ sunset yellow, tartrazine, and fast green FCA (Figure 6). Likewise, dislocated metaphase was only observed in sunset yellow, forwarded anaphase in tartrazine, bridge anaphase in fast green, and laggard anaphase in allura red FCA (Figure 7a-d). The DM, FA, and BA aberrations were detected highest at $1 \%$ concentration that was $33 \%, 27 \%$, and $21 \%$ respectively while, least at $0.001 \%$ concentration (Figure $7 \mathrm{a}-\mathrm{c}$ ). Additionally, LA was utmost (19\%) at $0.1 \%$ concentration of allura red but not perceived at $1 \%$ solution of allura red (Figure 7d).

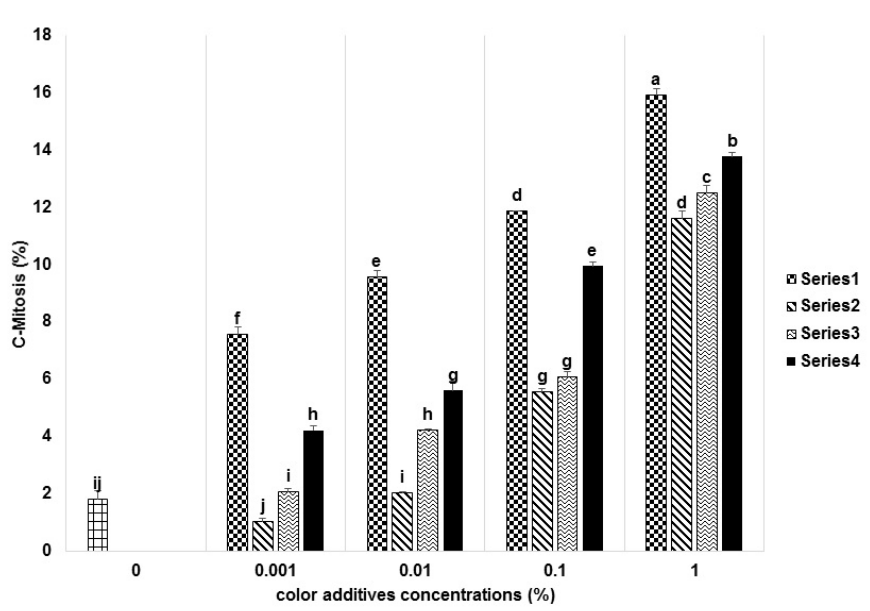

Figure 5: C-Mitosis in onion (Allium cepa) root tips treated with $0 \%, 0.001 \%, 0.01 \%, 0.1 \%$ and $1 \%$ concentration of four used food colour additives. The rest of the information same as Figure 2.

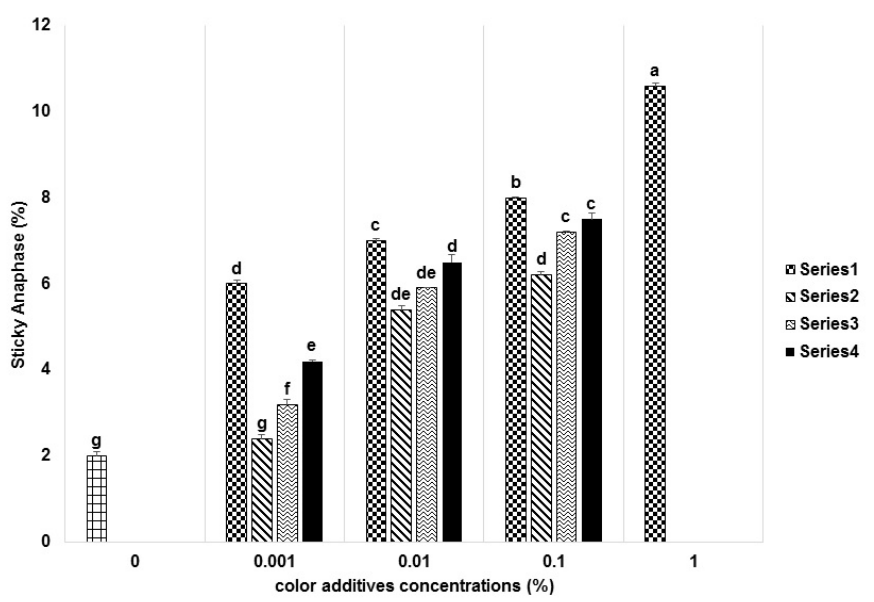

Figure 6: Sticky anaphase in onion (Allium cepa) root tips treated with $0 \%, 0.001 \%, 0.01 \%, 0.1 \%$ and $1 \%$ concentration of four used food colour additives. The rest of the information same as Figure 2.

Allium test is a quite simple and accurate tool to analyze the genotoxicity of various substances when compared with animal or human leukocytes test (Khan et al., 2020). Moreover, MI and chromosomal aberration studies are widely used to estimate the 
impact of cytotoxicity induced by test samples. In this report, the evaluated FCAs are extensively used in a variety of daily used food, medicines, and skin-related products. Present results indicated that the length, shape, and vigor of the onion bulb were severely affected as the concentration of FCAs was increased. These findings were positively concurrent with the outcomes of Fiskesjo (1985), Firbas and Amon (2013), and Gomes et al. (2013). As the length of onion root tips is a vital and sensitive factor induced by internal cellular activities and as well as external stimuli that have been affected due to the FCAs toxicity (Adeyemo and Farinmade, 2013). Moreover, the results of the study summarized in Figure 8, clearly demonstrated the cytotoxicity of used azo FCAs, in which allura red exhibited the highest level and types of chromosomal aberrations followed by fast green. Our findings were consistent with Khan et al. (2020), who observed optimum aberration when meristematic cells of onion roots were treated with a $1 \%$ concentration of red azo FCA then $1 \%$ metanil yellow azo FCA for $48 \mathrm{~h}$. Further, the red azo FCA inhibited more mitotic index and induced chromosomal breaks, disorientation at metaphase, C-mitosis, sticky metaphase, sticky anaphase, and bridge anaphase (Khan et al., 2020). Likewise, Floriano et al. (2018), reported that the tartrazine in a minute quantity like $70 \mu \mathrm{g} \mathrm{mL} \mathrm{m}^{-1}$ concentration induced DNA damages in ex vivo human leukocytes culture. According to ADMET software, the $1000000 \mu \mathrm{g} \mathrm{L}{ }^{-1}$ concentration of azo FCA may be killed $50 \%$ of the tested organism (Floriano et al., 2018). Furthermore, the toxicological studies of these azo FCAs revealed interference in the hydrogen bonds of chromosomes which caused oxidative stress and allergic responses (Kashanian and Zeidali, 2011). In another micronucleus study conducted on human lymphocytes revealed the mutagenic action of azo FCA at $2500 \mu \mathrm{g} \mathrm{mL}{ }^{-1}$ concentration (Sekeroglu et al., 2017). Likewise, the genotoxic and cytotoxic studies of turmeric yellow and sunset yellow FCA conducted on human lymphocyte culture showed significant structural and chromatid-associated aberrations at 4 and $8 \mathrm{mM}$ concentrations, proving its hazardous effect on human health (Haverić et al.,2018). Chequer et al. (2017) investigated the molecular impact and expression profile of cherry pink and tartrazine FCAs on human DNA repair genes and cell cycle. It was observed that azo FCAs significantly decreased the expression of LIG1, REV1, and FEN1 DNA base repair genes and enhance the expression of apoptosis gene $B A X, P P P 1 R 15 A$, these results revealed the genotoxic mechanism of azo dyes which corroborates well with the results of the current study.

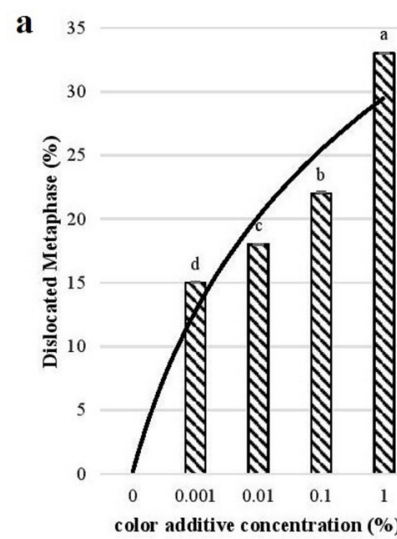

b 30
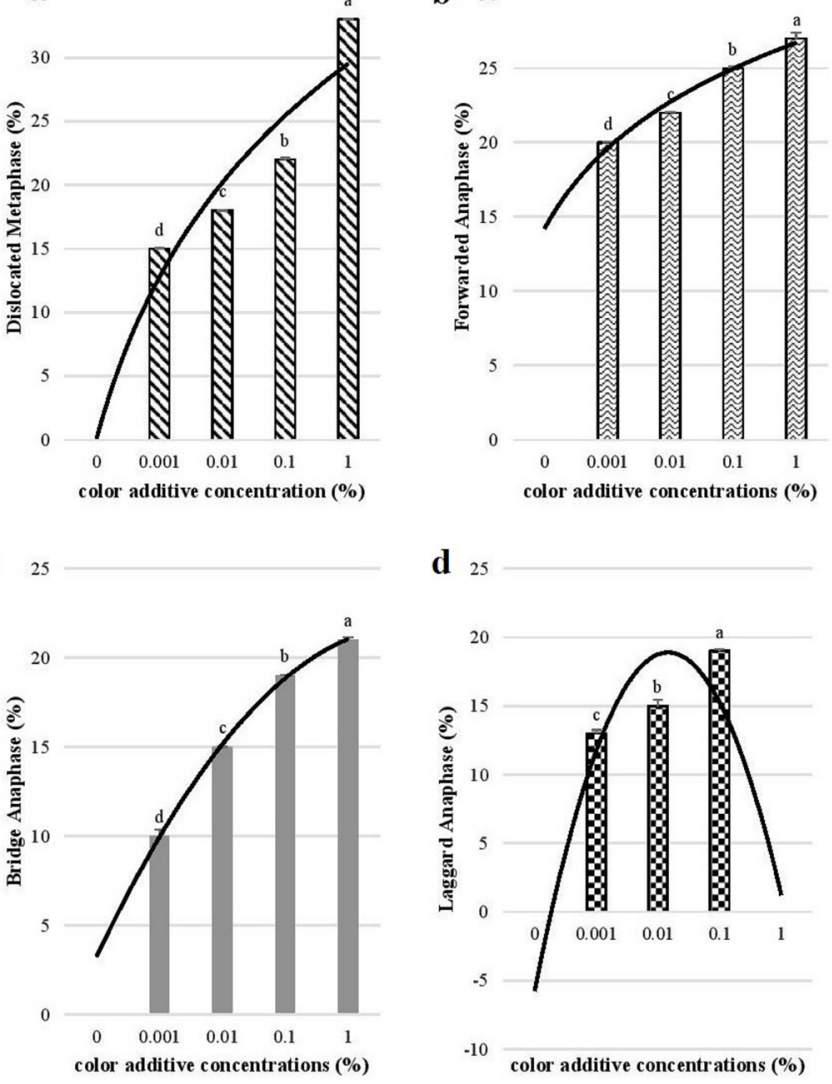

Figure 7: Various aberrations in onion (Allium cepa) root tips treated with $0 \%, 0.001 \%, 0.01 \%, 0.1 \%$ and $1 \%$ concentration of four used food colour additives. Similar letters are representing no difference among treatments of each FCA $(n=4)$. Where $a=$ dislocated metaphase; $b=$ forwarded anaphase; $c=$ bridge anaphase and $d=$ laggard anaphase .

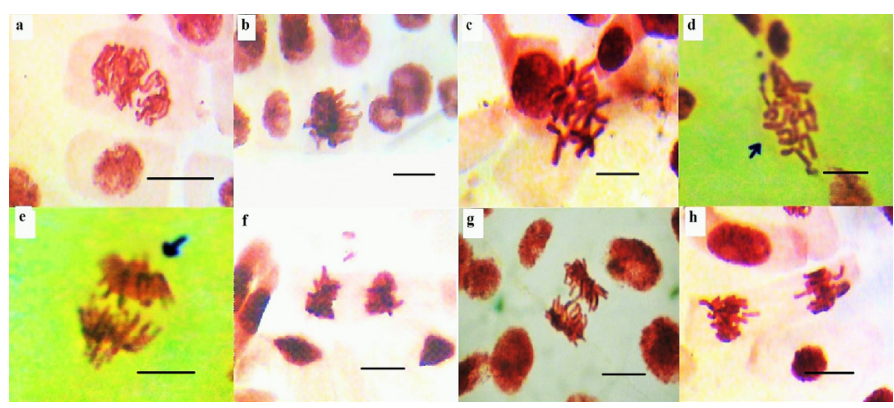

Figure 8: Microscopic study of onion (Allium cepa) root tips treated with $0 \%, 0.001 \%, 0.01 \%, 0.1 \%$ and $1 \%$ concentration of four food colour additive for $36 \mathrm{~h}$ (a). Abnormal prophase, (b). Sticky metaphase, (c). Dislocated metaphase, (d). C-Mitosis, (e). Forwarded anaphase, (f). Sticky anaphase, (g). Bridge anaphase and (h). Laggard anaphase. Scale bars $=5 \mu \mathrm{m}$ cell $^{-1}$. 
The current microscopic analysis demonstrated a decline in $\mathrm{MI}$ and intensification in abnormal prophase, sticky meta- and anaphase, c-mitosis, dislocated metaphase, forwarded, bridge, and laggard anaphase percentages. Our results significantly met with earlier reports on FCAs induce examined aberrations in onion (Gomes et al., 2013; Bezerra et al., 2016; Kaur et al., 2019; Khan et al., 2020). The discussed aberrations are due to the use of azo FCAs that either seize chromosome synthesis or cell division. The FCA's may bind to the tubulin protein which polymerizes into the chain-like structure named as microtubule (Adeyemo and Farinmade, 2013). The microtubule is responsible to create spindle fibers for normal cell division and chromosomes movement to their respective poles. According to Rath and Sethi (2017), a decrease in MI could be due to the hindrance in the synthesis phase of the cell cycle which prevents onion root tip cell division. The stickiness in chromosomes may be due to misfolding of DNA which afterward attached by their chromatids to each other (Badr, 1986), or maybe due to the increased contraction of chromosomes (Darlington, 1942), thus stickiness may have a toxic effect which may lead to the cell death (Kaur et al., 2019). The dislocated metaphase may be due to the loss of microtubules activity in spindle fibers, causing complete inhibition of spindle formation (Panday and Santosh, 2007). Furthermore, the bridges may be formed because of breakage and fusion of chromosomes ends (Turkoglu, 2009). Moreover, the occurrence of c-mitosis showed that these FCAs act as colchicine, who constrain the formation of mitotic spindle fibers. Similarly, forwarded and Laggard chromosomes are because of chromosomes movement or acentric fragments.

\section{Conclusion and Recommendations}

In short, studying structural chromosomal aberrations may be associated with the poor prognosis of solid tumor and cell lesions. Our results showed that all four concentrations of used FCAs (0.001-1\%), expressed a severe level of damages in onion bulb root cells in concentration-dependent manner. In conclusion, powdered or liquid FCAs like allura red, sunset yellow, tartrazine, and fast green are frequently used in cooking, baking, cosmetics, and medicines industries which have the potentials to be genotoxic. This investigation recommends that extensive use of azo FCAs should be forbidden due to the cytotoxic impacts on onion bulbs. Furthermore, there is an urgent need to develop organic food colour additives approved by Food Drug and Administration that will be evaluated through murine model examination.

\section{Novelty Statement}

The current findings will enable readers to understand the forthcoming health hazard of azo dyes that are widely used in commercial foods, fast food, frozen foods, bakery products, and daily cosmetics and realize the need and importance of organic dyes.

\section{Author's Contribution}

JF conceptualized the study, design the experiments, data curation, formal analysis, investigation, methodology, and drafting research findings. SM supervised the whole research findings and reviewing. MA prepared the slides and capture the images of the experiments.

\section{Conflict of interest}

The authors have declared no conflicts of interest.

\section{References}

Adeyemo, O.A. and Farinmade, A.E., 2013. Genotoxic and cytotoxic effects of food flavor enhancer, monosodium glutamate (MSG) using Allium cepa assay. Afr. J. Biotechnol., 12(13): 1459-1466.

Badr, A., 1986. Effect of the s-triazine herbicide turbutryn on mitosis, chromosomes and nucleic acids in root tips of Vicia faba. Cytologia, 51(3): 571-577. https://doi.org/10.1508/ cytologia.51.571

Bezerra, M.D., Malaquias, G., Castro e Sousa, J. and Peron, A., 2016. Cytotoxic and genotoxic potential of powdered juices. Food Sci. Technol. (Camp.). 36(1): 49-55. https://doi. org/10.1590/1678-457X.0006

Chequer, F.M.D., Venancio, V.P., Almeida, M.R., Aissa, A.F., Bianchi, M.L.P. and Antunes, L.M.G., 2017. Erythrosine B and. erythrosine $\mathrm{B}$ and quinolone yellow dyes regulate DNA repair gene expression in human HepG2 cells. Toxicol. Ind. Health, 33(10): 765-774. https:// doi.org/10.1177/0748233717715186

Clarke, H.T. and Kirner, W.R., 1941. Methyl red. Org. Synth. Coll., 2: 47. https://doi. org/10.1002/0471264180.os002.11 
Darlington, C.D., 1942. Chromosome chemistry and gene action. Nature, 149: 66-69. https:// doi.org/10.1038/149066a0

Dwivedi, K. and Kumar, G., 2015. Genetic damage induced by a food colouring dye (sunset yellow) on meristematic cells of Brassica campestris L. J. Environ. Public Health, Article ID 319727. https://doi.org/10.1155/2015/319727

Farheen, J. and Mansoor, S., 2019. Cytogenetic impact of sodium chloride stress on root cell of Vigna radiata L. seedlings. Turk. J. Biochem., 45(2): Article ID 20180352. https://doi. org/10.1515/tjb-2018-0352

Firbas, P. and Amon, T., 2013. Allium chromosomal aberrations test for evaluation effect of cleaning municipal water with constructed wetland (CW) in Sveti Tormaž, Slovenia. J. Bioremed. Biodeg., 4(4): 189-193. https://doi. org/10.4172/2155-6199.1000189

Fiskesjo, G., 1985. The Allium test as a standard in environmental monitoring. Heriditas, 102(1): 99-112. https://doi. org/10.1111/j.1601-5223.1985.tb00471.x

Floriano, J.M., de Rosa, E., do Amaral, Q.D.F., Zuravski, L., Chaves, P.E.E., Machado, M.M. and de Oliveira, L.F.S., 2018. Is tartrazine really safe? In silico and ex vivo toxicological studies in human leukocytes: A question of dose. Toxicol. Res., 7: 1128-1134. https://doi.org/10.1039/ C8TX00034D

Freitas, A.S., 2012. Tartrazina: Uma revisão das propriedades e análises de quantificação. Acta Tecnol., 7(2): 65-72. https://doi.org/10.35818/ acta.v7i2.90

Gomes, K.M.S., Oliveira, M.V.G.A., Carvalho, F.R.D., Menezes, C.C. and Peron, A.P., 2013. Cytotoxicity of food dyes sunset yellow (E-110), bordeaux red (E-123), and tartrazine yellow (E102) on Allium cepa L. root meristematic cells. Food Sci. Technol., 33(1): 218-223. https://doi. org/10.1590/S0101-20612013005000012

Haverić, A., Haverić, S., Hadžić, M., Lojo-Kadrić N. and Ibrulj, S., 2018. Genotoxicity and cytotoxicity analysis of curcumin and sunset yellow in human lymphocyte culture. Cell. Mol. Biol., 64(3): 87-91. https://doi.org/10.14715/ $\mathrm{cmb} / 2018.64 .3 .14$

Kashanian, S. and Zeidali, S.H., 2011. DNA binding studies of tartrazine food additive. DNA Cell Biol., 30(7): 499-505. https://doi. org/10.1089/dna.2010.1181
Kaur, S., Halady, P., Revathi, B., Bushra, L. and Swapna, 2019. Genotoxicity Induced by food coloring dyes on meristematic cells (Root Tips) of Allium Cepa. Intl. J. Trend Sci. Res. Dev., 3(4): 116-118. https://www.ijtsrd.com/papers/ ijtsrd23568.pdf https://doi.org/10.31142/ ijtsrd23568

Khan, I.S., Ali, Md.N., Hamid, R. and Ganie, S.A., 2020. Genotoxic effect of two commonly used food dyes metanil yellow and carmoisine using Allium cepa L. as indicator. Toxicol. Rep., 7: 370-375. https://doi.org/10.1016/j. toxrep.2020.02.009

Micic, R.J., Mitic, S., Pavlovic, A.N., Kostic, D.A. and Mitic, M.N., 2014. Application of tartrazine for sensitive and selective kinetic determination of $\mathrm{Cu}$ (II) traces. J. Anal. Chem., 69(12): 1147-1152. https://doi.org/10.1134/ S1061934814120107

Oliveira, M.V.A., Alves, D.D.L., Lima, L.H.D.M., Castro,J.M. and Peron, A.P., 2013. Cytotoxicity of erythrosine (E-127), brilliant blue (E-133) and re 40 (E-129) food dyes in a plant test system. Acta Scientarium: Biol. Sci., 35(4): 557562. https://doi.org/10.4025/actascibiolsci. v35i4.18419

Panday, R.M. and Santosh, U., 2007. Impact of food additives on mitotic chromosomes of Vicia faba L. Caryologia, 60(4): 309-314. https://doi. org/10.1080/00087114.2007.10797952

Rangan, C. and Barceloux, D.G., 2009. Food additives and sensitivities. Disease- $a$ Month, 55(5): 292-311. https://doi.org/10.1016/j. disamonth.2009.01.004

Rath, K.C. and Sethi, B., 2017. Cytotoxic effect of silk dyeing industry effluents on the mitotic cells of Allium cepa. Euro. J. Zool. Res., 5(2): 1016.

Rus, V., Gherman, C., Miclăuş, V., Mihalca, A. and Nadăş, G.C., 2010. Comparative toxicity of food dyes on liver and kidney in guinea pigs: a histopathological study. Ann. Romanian Soc. Cell Biol. 15(1): 161-165.

Sekeroglu, Z.A., Gunes, B., Yedier, S.K., Sekeroglu, V. and Aydin, B., 2017. Effects of tartrazine on proliferation and genetic damage in human lymphocytes. J. Toxicol. Mech. Methods 27(5): 370-375. https://doi.org/10.1080/15376516.2 017.1296051

Steel, R.G.D. and Torrie, J.H., 1997. Principles and procedures of statistics: A biometrical approach: 
$3^{\text {rd }}$ edn. Singapore: McGraw Hill Book Co. Vidal, M., Garcia-Arrona, R., Bordagaray, A., https://trove.nla.gov.au/version/26560275 Ostra, M. and Albizu, G., 2018. Si multaneous

Turkoglu, S., 2009. Genotoxic effect of mono-di-, and trisodium phosphate on mitotic activity, DNA content, and nuclear volume in Allium cepa L. Caryologia, 62(3): 171-179. https://doi. org/10.1080/00087114.2004.10589683 determination of colour additives tartrazine and allura red in food products by digital image analysis. Talanta, 184: 58-64. https://doi. org/10.1016/j.talanta.2018.02.111 